\title{
PENGESAMPINGAN PRINSIP PERSAMAAN DIMUKA HUKUM ATAS IZIN PEMERIKSAAN PEJABAT NEGARA
}

\author{
I Komang Suka'arsana, Maria Silvya E. Wangga \\ Fakultas Hukum Universitas Trisakti \\ Jl. Kyai Tapa No. 1 Grogol, Jakarta Barat \\ Email: komangsukarsana@gmail.com,mariasilvya@yahoo.com
}

\begin{abstract}
The principle of equality before the law (equality before the law) became an interesting topic to be studied after the decision of the Constitutional Court Number 76 PUU-XII / 2014. Such decision implies' not all citizens have equal status before the law ". This is reflected in the Constitutional Court's decision can be read, checking and calling on members of the House require the President's approval. The close relationship between the president permit the examination of members of Parliament with the principle of equality before the law (equality before the law) shows that not all citizens be treated equally before the law. This paper examines the overriding principle of equality before the law for state officials, especially the House of Representatives. The study results conclude the overriding principle of equality before the law only in the context of a procedural nature not escape criminal liability. It is necessary for the supervision of mechanisms permission so it does not hinder the trial process.
\end{abstract}

Keywords: Equality Before The Law; Examination Permit.

\begin{abstract}
Abstrak
Prinsip persamaan dimuka hukum (equality before the law) menjadi topikyang menarik untuk dikaji pasca putusan Mahkamah Konstitusi Nomor 76 PUU-XII/2014. Putusan tersebut mengandung makna 'tidak semua warga negara memiliki kedudukan yang sama dimuka hukum". Hal ini tercermin dari Putusan Mahkamah Konstitusi yang dapat dibaca, pemeriksaan dan pemanggilan terhadap anggota DPR memerlukan izin presiden. Kaitan yang erat antara ijin Presiden atas pemeriksaan anggota DPR dengan prinsip persamaan dimuka hukum (equality before the law) memperlihatkan bahwa tidak semua warga negara dapat diperlakukan sama dimuka hukum. Tulisan ini mengkaji pengesampingan prinsip persamaan dimuka hukum bagi pejabat negara khususnya DPR. Hasil kajian menyimpulkan pengesampingan prinsip persamaan dimuka hukum hanya bersifat prosedural bukan dalam konteks bebas dari pertanggungjawaban pidana. Untuk itu diperlukan pengawasan atas mekansime izin sehingga tidak menghambat proses persidangan.
\end{abstract}

Kata kunci: Persamaan Dimuka Hukum; Ijin Pemeriksaan

\section{A. Pendahuluan}

Prinsip persamaan dimuka hukum (equality before the law) menjadi topik yang menarik untuk dikaji pasca putusan Mahkamah Konstitusi Nomor 76 PUUXII/2014. Putusan tersebut mengandung makna 'tidak semua warga negara memiliki kedudukan yang sama dimuka hukum". Hal ini tercermin dari Putusan Mahkamah Konstitusi yang dapat dibaca, pemeriksaan dan pemanggilan terhadap anggota DPR memerlukan izin presiden. Kaitan yang erat antara ijin Presiden atas pemeriksaan anggota
DPR dengan prinsip persamaan dimuka hukum (Equality before the law) memperlihatkan bahwa tidak semua warga negara dapat diperlakukan sama dimuka hukum. Persamaan setiap warga negara dimuka hukum (equality before the law) mengandung arti setiap warga negara tetap sama dimuka hukum, baik kesamaan menjalankan proses hukum acaranya maupun kesamaan dalam mentaati perintah-perintah yang dilarang dan diwajibkan oleh undangundang, yang dimaknai kesamaan mentaati substansi hukum, yang dalam hukum pidana 
dikenal dengan asas legalitas.

Mekanisme izin Presiden bukanlah produk hukum yang dikenal dalam KUHAP, tetapi produk politik. Atas dasar hal tersebut diatas, maka penulis akan mengkaji mengenai pemahaman prinsip persamaan dimuka hukum (equality before the law) dari aspek substansi hukum dan hukum acara pidana bagi setiap warga masyarakat serta apakah pengesampingan prinsip persamaan dimuka hukum (equality before the law) yang diperoleh anggota DPR bersifat mutlak (absolut).

\section{B. Pembahasan}

1. Pemahaman Prinsip Persamaan Dimuka Hukum Dari Aspek Substansi Hukum dan Hukum Acara Pidana

Prinsip persamaan dimuka hukum (equality before the law) dikemukakan Cesare Beccaria (1738-1794), ahli Ekonomi, matematika dan politik dari Italia, yang vokal menentang kesewenang-wenangan penguasa pada saat itu melalui bukunya yang berjudul "Dei delitti e delle pene". Prinsip ini diterapkan dalam Undang-Undang yang dikenal dengan Code Civil Napoleon 1791 di Perancis, yang kemudian diadopsi Belanda, hingga dibawa ke indonesia karena sebagai negara jajahannya. Prinsip persamaan dimuka hukum (equality before the law) diartikan ketidakberpihakan terhadap setiap warga masyarakat di mata hukum sehingga dapat dituntut dengan derajat yang sama, tanpa membeda-bedakannya.

Pada tahun 1974 pemerintah menggambarkan Prinsip persamaan dimuka hukum (equality before the law) disimbolkan dengan gambar Dewi Yustitia, yang memegang pedang di salah satu tangannya dan timbangan pada tangan lainnya dengan menggunakan penutup mata. ${ }^{3}$ Iustisia atau justitia adalah personifikasi Dewi keadilan Romawi Kuno yang memiliki makna keadilan harus diterapkan secara obyektif, tanpa rasa takut, terlepas dari identitas, uang, kekuasaan, atau kelemahan dan ketidakberpihakan. Simbol ini diusulkan untuk diganti oleh Soekarno karena simbol Dewi justitia adalah Dewi Yunani, yang tidak sesuai dengan budaya dan sosial indonesia sehingga simbol tersebut diganti dengan pohon beringin.

Prinsip persamaan dimuka hukum (equality before the law) dituangkan dengan jelas dalam Konstitusi, Pasal 27 ayat (1) UUD 1945 yang berbunyi, "segala warga negara bersamaan kedudukannya dalam hukum dan pemerintahan dan wajib menjunjung hukum dan pemerintahan itu dengan tidak ada kecualinya". Bahkan Pasal 28D ayat (1) UUD 1945 menyatakan, "setiap orang berhak atas pengakuan, jaminan, perlindungan dan kepastian hukum yang adil serta perlakuan yang sama dimuka hukum". Prinsip dasar ini diatur lebih lanjut dalam ketentuan beracara hukum pidana, seperti Penjelasan Umum KUHAP butir 3 a yang merumuskan, "perlakuan yang sama atas diri setiap orang di muka hukum dengan tidak mengadakan pembedaan perlakuan". Selanjutnya dalam Pasal 4 Undang-Undang Nomor 48 Tahun 2009 tentang Kekuasaan Kehakiman dinyatakan, "Pengadilan mengadili menurut hukum dengan tidak membeda-bedakan".

Prinsip persamaan dimuka hukum (equality before the law) atau setiap warga masyarakat diperlakukan sama dimuka hukum, memiliki makna setiap warga masyarakat, baik warga biasa maupun pejabat akan mendapat perlakuan yang sama secara substansi hukum pidana maupun secara prosedural (hukum acaranya). Perlakuan yang sama secara substansi hukum pidana adalah setiap orang mentaati dan menghormati, aturan-aturan hukum pidana, yang dilarang atau diwajibkan, yang telah diatur dalam undang-undang sebagai perbuatan yang dilarang. Aturan hukum pidana merupakan ketentuan yang berisi perintah dan larangan, yang apabila dilanggar akan dikenai sanksi, sedangkan perbuatan pidana (strafbaar feit) adalah kelakuan yang

\footnotetext{
1. Topo Santoso dan Eva Achjani Zulfa, 2003, Kriminologi, Jakarta, Rajawali Pers, hlm. 5 lihat juga Ahmad Ulil Aedi, "Rekonstruksi Asas Kesamaan di Hadapan Hukum (Equality Before The Law) (Suatu Kajian Khusus Putusan Mahkamah Konstitusi Perkara 21-22/PUU-V/2007 Dalam Perspektif Filsafat Hukum”, Jurnal Law Reform, Vol. 8, No. 2, Tahun $2013 \mathrm{hlm} 1$

2. Koesriani Siswosoebroto, 2004, Modul Kriminologi, Jakarta, FH USAKTI, hlm. 7

3. Ibid.
} 
diancam pidana, yang bersifat melawan hukum yang berhubungan dengan kesalahan dan dilakukan oleh orang yang mampu bertanggung jawab, demikian pandangan simons yang dikutip Andi Hamzah. ${ }^{4}$

Van Hamel merumuskan perbuatan pidana (strafbaar feit), sebagai eene wettelijke omschreven mensschelijke gedraging, onrechtmatig, strafwaardig en aan schuld te wijten, oleh Andi hamzah diterjemahkan sebagai; kelakuan manusia yang dirumuskan dalam undang-undang, melawan hukum, yang patut dipidana dan dilakukan dengan kesalahan. Uraian di atas, secara eksplisit terdapat dalam Pasal 1 ayat (1) KUHP, yang dikenal sebagai asas legalitas, yang oleh Anselm von Feuerbach dengan psycologishe dwang, yang artinya untuk menentukan perbuatan-perbuatan yang dilarang dalam suatu undang-undang pidana, tidak hanya perbuatan tersebut dituliskan dengan jelas dalam undang-undang pidana, tetapi juga mengenai ancaman pidananya yang akan dikenakan. ${ }^{6}$ Dengan demikian agar orang yang melakukan perbuatan pidana mengetahui lebih dahulu perihal pidana yang diancamkan sehingga ia memiliki perasaan takut dalam batin untuk tidak melakukan perbuatan yang dilarang. ${ }^{7}$

Prinsip kesamaan substansi hukum pidana yang diuraikan dengan Pasal 1 ayat (1) KUKP berlaku sama untuk semua orang baik, warga masyarakat biasa maupun pejabat negara, termasuk DPR. Artinya perbuatan pidana yang dilakukan oleh anggota DPR, hanya dapat diadili menurut aturan hukum yang berlaku pada waktu perbuatan dilakukan (lex temporis delictie). ${ }^{8}$ Tindak pidana yang dilakukan oleh Anggota DPR pada waktu tertentu dan tempat tertentu, harus telah ada undang-undang yang mengatur perbuatan tersebut sebagai perbuatan pidana sehingga memenuhi unsur-unsur deliknya.

Penerapan prinsip kesamaan hukum acara pidana bagi setiap warga masyarakat mengacu pada ketentuan KUHAP. Artinya untuk laporan, informasi, pengaduan atau tertangkap tangan yang memenuhi unsur tindak pidana harus melandasi pada sumber hukum Pasal 1 ayat (1) KUHP, yang memiliki makna antara lain: ${ }^{9}$

a. Nullum delictum, nulla poena sine praevia lege poenali, artinya tiada delik, tiada pidana, tanpa peraturan yang mengancam pidana terlebih dahulu;

b. Undang-undang hukum pidana tidak mempunyai kekuatan berlaku surut;

c. Lex temporis delicti, artinya undangundang berlaku terhadap delik yang terjadi pada saatitu.

Prinsip kesamaan hukum acara pidana yang diberlakukan pada setiap warga masyarakat yang menjalani proses penyelidikan, penyidikan, pemeriksaan baik sebagai saksi, status tersangka atau ahli diperlakukan sama sesuai ketentuan yang ada dalam KUHAP. Mekanisme pemeriksaan bagi setiap warga masyarakat diatur dalam Pasal 112 KUHAP dan Pasal 227 ayat (1) KUHAP dilakukan langsung oleh aparat penegak hukum melalui surat panggilan yang berisi, antara lain: ${ }^{10}$

a. Identitas diri (nama dan alamat yang jelas orang yang dipanggil);

b. Nama penyidik yang harus ditemui;

c. Tempat (alamat kantor) untuk memenuhi panggilan;

d. Waktu (hari, tanggal, bulan, tahun jam) untuk memenuhi panggilan;

e. Status orang yang dipanggil, sebagai tersangka atau sebagai saksi;

f. Uraian singkat perkara tindak pidana yang terjadi dan Pasal yang dilanggar;

g. Surat panggilan ditandatangani pejabat penyidik.

Surat panggilan yang telah dipersiapkan aparat hukum yang berwenang merupakan bentuk pemberitahuan atau panggilan dalam semua tingkat pemeriksaan kepada saksi, tersangka atau terdakwa dan

4. Andi hamzah, 2005, Asas-Asas Hukum Pidana, Jakarta, PT. YarsifWatampone, hlm 97.

5. Ibid

6. Eddy O. S. Hiariej, "Pemikiran Remmelink Mengenai Asas Legislasi”, Jentera Jurnal Hukum, Vol. 4, No. 16, AprilJuni 2007, hlm.126

7. Ibid

8. Moeljatno, 1993, Asas-Asas Hukum Pidana, Jakarta, PT. Rineka Cipta. hlm, 31.

9. Bambang Poernomo, 1994, Asas-Asas Hukum Pidana, Jakarta, Ghalia Indonesia, hlm. 68

10. Ramelan, 2006, Hukum Acara Pidana Teori dan Implementasi, Jakarta, Sumber Ilmu Jaya, hlm.74 
ahli dengan tata cara pemanggilan sebagai berikut:

a. Surat panggilan disampaikan selambatlambatnya (3) hari sebelum tanggal yang bersangkutan hadir, di tempat tinggal atau tempat kediaman terakhir, dalam Pasal 227 ayat (1) KUHAP;

b. Petugas yang melaksanakan panggilan tersebut harus bertemu sendiri dan berbicara langsung dengan orang yang dipanggil dan membuat catatan bahwa panggilan telah diterima oleh yang bersangkutan dengan membubuhkan tanggal serta tandatangan, baik oleh petugas maupun orang yang dipanggil dan apabila yang dipanggil tidak menandatangani maka petugas harus mencatat alasannya, dalam Pasal 227 ayat (2) KUHAP;

c. Dalam hal orang yang dipanggil tidak terdapat di satu tempat sebagaimana yang dimaksud dalam ayat (1), surat panggilan disampaikan melalui kepala Desa atau pejabat dan jika di luar negeri melalui perwakilan RI di tempat dimana orang yang dipanggil biasa berdiam dan apabila masih belum juga berhasil disampaikan maka surat panggilan ditempelkan di tempat pengumuman kantor pejabat yang mengeluarkan surat panggilan tersebut, dalam Pasal 227 ayat (3) KUHAP.

Saksi atau tersangka yang telah menerima surat panggilan akan memenuhi dan menjalani proses pemeriksaan yang akan dilakukan aparat hukum yang berwenang. Apabila dari hasil pemeriksaan ditemukan bukti permulaan yang menunjukkan adanya tindak pidana maka aparat akan melalukan berbagai upaya paksa seperti penangkapan, penahanan, penggeledahan dan penyitaan hingga melimpahkan berkas hasil penyidikan kepada Penuntut Umum. Hasil pemeriksaan dalam tahap pra penuntutan, yang menyatakan berkas hasil penyidikan telah cukup bukti dapat segera dilimpahkan untuk disidangkan di pengadilan. Uraian penerapan prinsip persamaan dimuka hukum (equality before the law), baik persamaan substansi hukum maupun proseduralnya berlaku adil, merata dan tidak berpihak serta terlepas dari uang, dan kekuasaan.

\section{Pengesampingan Prinsip Persamaam Dimuka Hukum (Equality Before the law) Bagi Pejabat Negara}

Pengaturan izin pemeriksaan pejabat negara tidak dikenal dalam konteks pertanggungjawaban perbuatan pidana. Awal mulanya izin pemeriksaan bagi pejabat negara di indonesia bermula dari konsep "forum privilegiatum" yang merupakan kewenangan Hoge Raad Belanda. Konsep ini kemudian diadopsi melalui Pasal 106 UUDS 1950 yang, menyatakan:

"Presiden dan Wakil Presiden, MenteriMenteri, Ketua, Wakil Ketua dan Anggota Dewan Perwakilan Rakyat, Ketua, Wakil Ketua dan Anggota Mahkamah Agung, Djaksa Agung pada Mahkamah Agung, Ketua, Wakil Ketua dan Anggota Dewan Pengawas Keuangan, Presiden Bank Sirkulasi dan juga pegawa-pegawai, anggotaanggota majelis-majelis tinggi dan pejabat-pejabat lain yang ditunjuk dalam undang-undang, diadili dalam tingkat pertama dan tertinggi juga oleh Mahkamah Agung, pun sesudah mereka berhenti, berhubung dengan kejahatan dan pelanggaran lain yang ditentukan dengan undang-undang dan yang dilakukannya dalam masa pekerjaannya kecuali jika ditetapkan lain dengan undang-undang".

"Forum privilegiatum" adalah hak khusus yang dimiliki oleh pejabat-pejabat tinggi untuk diadili oleh suatu pengadilan yang khusus/tinggi dan bukan oleh pengadilan negeri. ${ }^{12}$ Dalam Undang-Undang Darurat Nomor 29 Tahun 1950 tentang Penetapan Kejahatan-Kejahatan dan Pelanggaran-Pelanggaran yang dilakukan dalam masa pekerjaan oleh Para Pejabat. Rumusan forum privilegiatum diadopsi kembali dengan diberlakukannya UUD RIS 1949. Dalam Pasal 148 Konstitusi Republik

\footnotetext{
11. Bivitri Susanti, "Mahkamah Kehormatan Dewan Dalam konteks Negara Hukum”, tersedia di website http://icjr.or.id/data/wp-content/uploads/2014/08/keteranganahli-UU-MD3-Bivitri-Susanti, pdf, diakses pada tanggal 30 september 2015.

12. Tersedia di website http:www//.miftakhulhuda.com/2010/01/forum-previlegiatum, diakses pada tanggal 30 September 2015
} 
Indonesia Serikat dalam Tingkat Pertama dan Tertinggi diadili oleh Mahkamah Agung, ditentukan kejahatan dan pelanggaran tersebut yaitu:

a) Kejahatan-kejahatan yang diancam dengan hukuman mati;

b) Kejahatan-kejahatan yang termaksud dalam KUHP, Buku kedua titel I, II dan III;

c) Kejahatan-kejahatan dan pelanggaranpelanggaran yang dilakukannya dalam keadaan yang memberatkan kesalahannya sebagaimana termaksud dalam Pasal 52 KUHP.

Persidangan khusus yang diterapkan ini berlaku hanya diperuntukan bagi pejabat negara. Beberapa unsur pimpinan setingkat Menteri yang pernah menjalani persidangan khusus melalui mekanisme forum previlegiatum adalah Menteri Negara Sultan Hamid, Menteri Luar Negeri Ruslan Abdulgani, Menteri Kehakiman Djodi Gondokusumo dan beberapa pejabat lainnya. Sejak pemerintah indonesia memberlakukan UUD 1945, dalam tahun 1959 persidangan khusus melalui forum previlegiatum tidak berlaku sehingga Mahkamah Agung menetapkan untuk tidak menerapkan yurisdiksi tersebut, setelah diberlakukan Undang-Undang Mahkamah Agung dan Undang-Undang Kekuasaan Kehakiman.

Meskipun Persidangan khusus bagi pejabat negara telah ditiadakan, namun ditemukan pengaturan tentang hak-hak khusus bagi pejabat negara. Salah satunya hak imunitas yang diperoleh anggota DPR, jika akan dipanggil atau diperiksa oleh aparat berwenang sebagaimana dirumuskan dalam Pasal 224 Undang-Undang Nomor 17 Tahun 2014 tentang MPR, DPR, DPD.

Hak khusus melalui izin Mahkamah Kehormatan Dewan diajukan judicial review ke Mahkamah Konstitusi. Majelis hakim Mahkamah Konstitusi melalui amar Putusan Nomor 76 PUU-XII/2014, menyatakan "frasa persetujuan tertulis Mahkamah Kehormatan Dewan", dalam Pasal 245 ayat (1) UndangUndang Nomor 17 Tahun 2014 tentang MPR, DPR, DPD dan DPRD bertentangan dengan
UUD 1945 dan tidak mempunyai kekuatan hukum mengikat, sepanjang tidak dimaknai persetujuan tertulis dari presiden", pemanggilan dan permintaan keterangan untuk penyidikan terhadap anggota DPR yang diduga melakukan tindak pidana harus mendapat "persetujuan tertulis dari Presiden".

Amar putusan hakim Mahkamah Konstitusi didasari pertimbangan bahwa "persyaratan persetujuan tertulis Mahkamah Kehormatan Dewan dalam hal pemanggilan dan permintaan keterangan untuk penyidikan terhadap anggota DPR bertentangan dengan prinsip persamaan dimuka hukum dan pemerintahan. proses penyidikan terhadap anggota DPR yang diduga melakukan tindak pidana memerlukan persetujuan Mahakmah Kehormatan Dewan adalah tidak tepat, mengingat Mahkamah Kehormatan Dewan adalah alat kelengkapan DPR yang merupakan lembaga etik, yang anggotanya dari dan oleh anggota DPR, yang akan menimbulkan konflik kepentingan bahkan tidak memiliki hubungan langsung dengan sistem peradilan pidana, karenanya proses persetujuan tertulis terhadap anggota DPR yang kepadanya akan dilakukan penyidikan maka persetujuan tertulis haruslah dikeluarkan oleh presiden dalam kedudukannya sebaga kepala negara, yang akan diterbitkan dalam waktu yang singkat dalam rangka mewujudkan proses hukum yang berkeadilan, efektif dan efisien serta menjamin adanya kepastian hukum". Pemberian persetujuan tertulis dari presiden kepada pejabat negara yang sedang mengalami proses hukum, khususnya penyidikan, telah diatur dalam beberapa Undang-Undang, antara lain UndangUndang Mahkamah Konstitusi, UndangUndang Badan Pemeriksaan Keuangan dan Undang-Undang Mahkamah Agung sehingga bukan merupakan hal yang baru".

Pemberian Izin terhadap pejabat negara dalam menghadapi proses hukum yang diatur dalam beberapa ketentuan Perundangundangan akan ditampilkan sebagaimana di dalam Tabel 1.

13. Kejaksaan Republik Indonesia, tersedia diwebsite https://www.kejaksaan.go.id/unit diakses pada tanggal 30 September 2015, pukul 10.37 
Tabel 1. Pemberian Izin Terhadap Pejabat Negara

\begin{tabular}{|c|c|c|c|}
\hline No & Pejabat & Undang-Undang & Keterangan \\
\hline 1 & Kepala daerah & $\begin{array}{lrr}\text { UU No. } & 23 & \text { Tahun } 2014 \\
\text { tentang } & & \text { Pemerintahan } \\
\text { Daerah } & & \end{array}$ & $\begin{array}{l}\text { Izin presiden untuk tahap } \\
\text { penyelidikan dan penyidikan } \\
\text { suatu tindak pidana tidak } \\
\text { dibutuhkan kecuali untuk } \\
\text { tindakan penahanan }\end{array}$ \\
\hline 2 & Mahkamah & $\begin{array}{lrr}\text { UU No.8 } & \text { Tahun } & 2011 \\
\text { tentang Perubahan } & \text { Atas } \\
\text { UU No. 24 } & \text { Tahun 2003 } \\
\text { tentang } & \text { Mahkamah } \\
\text { Konstitusi } & \end{array}$ & $\begin{array}{l}\text { Hakim konstitusi hanya dapat } \\
\text { dikenai tindakan tindakan } \\
\text { kepolisian atas perintah Jaksa } \\
\text { Agung setelah mendapat } \\
\text { persetujuan tertulis dari presiden }\end{array}$ \\
\hline 3 & Mahkamah & $\begin{array}{l}\text { UU No. 14 Tahun } 1985 \\
\text { tentang Mahkamah Agung } \\
\text { jo UU No. } 5 \text { Tahun } 2004 \\
\text { tentang Perubahan atas } \\
\text { UU No. } 14 \text { Tahun } 1985 \\
\text { tentang Mahkamah Agung }\end{array}$ & $\begin{array}{l}\text { Ketua, Wakil ketua, Ketua } \\
\text { Muda, dan Hakim Anggota } \\
\text { Mahkamah Agung dapat } \\
\text { ditangkap atau ditahan hanya } \\
\text { atas perintah Jaksa Agung } \\
\text { setelah mendapat persetujuan } \\
\text { Presiden }\end{array}$ \\
\hline 4 & Hakim Pengadilan & $\begin{array}{l}\text { UU No.2 Tahun } 1986 \\
\text { tentang Peradilan Umum } \\
\text { jo UU No.8 Tahun } 2004 \\
\text { tentang Perubahan Atas } \\
\text { UU No. } 2 \text { Tahun 1984 } \\
\text { tentang Peradilan Umum, } \\
\text { UU No.5 Thn } 1986 \\
\text { tentang Peradilan Tata } \\
\text { Usaha Negara, jo UU No.9 } \\
\text { Thn 2004 tentang } \\
\text { Perubahan Atas UU No.5 } \\
\text { Thn 1986 ttg Peradilan } \\
\text { Tata Usaha Negara, dan } \\
\text { UU No.7 Thn 1989 } \\
\text { tentang Peradilan Agama }\end{array}$ & $\begin{array}{l}\text { Penangkapan dan penahanan } \\
\text { terhadap hakim dilakukan atas } \\
\text { perintah Jaksa Agung setelah } \\
\text { mendapat persetujuan dari Ketua } \\
\text { Mahkamah Agung }\end{array}$ \\
\hline 5 & $\begin{array}{l}\text { Pimpinan dan Anggota } \\
\text { Dewan Gubernur Bank } \\
\text { Indonesia }\end{array}$ & $\begin{array}{l}\text { UU No.23 Thn 1999 } \\
\text { tentang Bank Indonesia jo } \\
\text { UU No.3 Tahun 2004 } \\
\text { tentang Perubahan Atas } \\
\text { UU No.23 Tahun 1999 } \\
\text { tentang Bank Indonesia }\end{array}$ & $\begin{array}{l}\text { Pemanggilan, permintaan } \\
\text { keterangan penyidikan terhadap } \\
\text { anggota Dewan Gubernur Bank } \\
\text { Indonesia harus mendapat } \\
\text { persetujuan tertulis dari Presiden }\end{array}$ \\
\hline 6 & Jaksa & 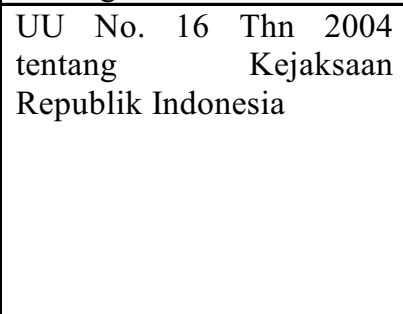 & $\begin{array}{l}\text { Apabila dalam melaksanakan } \\
\text { tugas jaksa diduga melakukan } \\
\text { tindak pidana, maka } \\
\text { pemanggilan, pemeriksaan, } \\
\text { penggeledahan, penangkapan } \\
\text { dan penahanan terhadap jaksa } \\
\text { yang bersangkutan hanya dapat } \\
\text { dilakukan atas izin Jaksa Agung. }\end{array}$ \\
\hline
\end{tabular}

Merujuk pada Tabel 1, maka dapat dilihat bahwa pengesampingan yang diterima pejabat negara termasuk anggota DPR bersifat prosedural (parsial) bukan pengesampingan yang mutlak (absolut). Pemeriksaan dan pemanggilan terhadap setiap warga masyarakat tidak dapat diterapkan sama dimuka hukum. Terhadap pejabat negara diberikan perlakuan khusus untuk menjaga kewibaan atau identitas negara yang melekat melalui jabatan yang sedang diterima oleh pejabat negara tersebut. Lingkup pejabat negara yang mendapat perlakuan khusus masih terbatas pada beberapa pejabat negara yang dirumuskan dalam Undang-Undang di atas. 


\section{Simpulan}

Berdasarkan uraian di atas, pengesampingan prinsip kesamaan dimuka hukum bagi pejabat negara tercermin melalui hak-hak khusus. Pengesampingan tersebut memperlihatkan tidak semua warga negara memiliki kedudukan yang sama dimuka hukum sebagaimana yang dinyatakan dalam Konstitusi. Artinya ada warga negara yang memiliki hak-hak khusus, dan ada yang warga negara yang tidak mendapatkan kekhususan tersebut. Berkaitan dengan hak-hak khusus tersebut terjadi contradictio in terminis dengan Pasal dalam Konstitusi. Pengesampingan yang diperoleh pejabat negara, khususnya anggota DPR bukanlah kebal hukum tetapi bersifat prosedural. Artinya pengesampingan prinsip persamaan dimuka hukum tidak dalam konteks bebas dari pertanggungjawaban pidana.

Sehubungan dengan uraian di atas, diperlukan pengawasan atas hak khusus tersebut, seperti mekanisme izin yang transparan sehingga tidak menghambat pertanggungjawaban pidana melalui proses persidangan. Upaya untuk menjaga kewibawan negara yang melekat pada pejabat negara tersebut, dapat diakomodir melalui persidangan khusus untuk menjangkau lingkup pejabat negara lainnya.

\section{Daftar Pustaka}

Aedi Ahmad Ulil, "Rekonstruksi Asas Kesamaan di Hadapan Hukum (Equality Before The Law) (Suatu Kajian Khusus Putusan Mahkamah Konstitusi Perkara 21-22/PUU-V/2007 Dalam Perspektif Filsafat Hukum", Jurnal Law Reform, Vol. 8, No. 2, Tahun 2013

Hamzah Andi, 2005, Asas-Asas Hukum Pidana, Jakarta, PT. YarsifWatampone

Hiariej Eddy O. S, "Pemikiran Remmelink Mengenai Asas Legislasi", Jentera Jurnal Hukum, Vol. 4, No. 16, AprilJuni 2007

Poernomo Bambang, 1994, Asas-Asas Hukum Pidana, Jakarta, Ghalia Indonesia

Moeljatno, 1993, Asas-Asas Hukum Pidana, Jakarta, PT. Rineka Cipta

Ramelan, 2006, Hukum Acara Pidana Teori dan Implementasi, Jakarta, Sumber Ilmu Jaya

Santoso Topo dan Eva Achjani Zulfa, 2003, Kriminologi, Jakarta, Rajawali Pers

Siswosoebroto Koesriani, 2004, Modul Kriminologi, Jakarta, FH USAKTI

Susanti Bivitri, "Mahkamah Kehormatan Dewan Dalam konteks Negara Hukum", tersedia di website h t t p : / i c j r.or.id/data/wp content/uploads/2014/08/keteranganah li-UU-MD3-Bivitri-Susanti, pdf, diakses pada tanggal 30 september 2015

Undang-Undang Dasar 1945

Undang-Undang Nomor 8 Tahun 1981 tentang Kitab Undang-Undang Hukum Acara Pidana

Undang-Undang Nomor 48 Tahun 2009 tentang Kekuasaan Kehakiman, Undang-Undang Nomor 17 Tahun 2014 tentang MPR, DPR, DPD dan DPRD

Putusan Mahkamah Konstitusi Nomor 73/PUU-IX/2012

Putusan Mahkamah Konstitusi Nomor 76 PUU-XII/2014

Kejaksaan Republik Indonesia, tersedia di $\mathrm{w}$ e b s i t e h t t p s: / / w w w . kejaksaan.go.id/unit diakses pada tanggal 30 September 2015

Tersedia di website http:www//. miftakhulhuda.com/2010/01/forumprevilegiatum, diakses pada tanggal 30 September 2015 